\title{
MECHANICAL PROPERTIES OF CHEMICALLY MODIFIED PORTUGUESE PINEWOOD
}

\author{
Duarte B.Lopes ${ }^{1,2, \wedge}$, Carsten Mai' ${ }^{2}$ Holger Militz ${ }^{2}$
}

\begin{abstract}
To turn wood into a construction material with enhanced properties, many methods of chemical modification have been developed in the last few decades. In this work, mechanical properties of pine wood were chemically modified, compared and evaluated.

Maritime pine wood (Pinus pinaster) was modified with four chemical processes: 1,3-dimethylol-4,5dihydroxyethyleneurea, N-methylol melamine formaldehyde, tetra-alkoxysilane and wax. The following mechanical properties were assessed experimentally: Modulus of elasticity measured statically, stiffness stabilization efficiency in different climates (30 and $87 \%$ of relative humidity), modulus of rupture, work maximum load, impact bending strength, compression, tensile and shear strength at indoor conditions $(65 \%$ of relative humidity).

In both types of active principle of modification, cell wall or lumen fill, no significant changes on the bending stiffness (modulus of elasticity) were found. In the remaining properties analysed significant changes in the modified wood-material took place compared to unmodified wood control:

- Cell wall modification was the most effective method to achieve high stiffness stabilization efficiency (up to $60 \%$ ) and also increased compression strength (up to $230 \%$ ). However, modulus of rupture, tensile, shear and the impact bending strength were reduced by both resins, but in a varying extent, where the N-methylol melamine formaldehyde endured less reduction than 1,3-dimethylol-4,5-dihydroxyethyleneurea resin. In the latter, reduction up to $60 \%$ can take place.

- In the lumen fill modification: tetra-alkoxysilane has no effect in the mechanical properties. Although, a slight increase in shear strength parallel to the grain was found. Wax specimens have shown a slight increase in bending strength, compression, tensile and shear strength as well as in the absorption energy capacity.
\end{abstract}

Keywords: Compression, impact bending strength, mechanical, modulus of elasticity, modulus of rupture, shear, stiffness stabilization efficiency, strength, tensile.

\footnotetext{
${ }^{1}$ School of Engineering-Polytechnic of Porto, Rua Dr. António Bernardino de Almeida, 431 4200-072. Porto - Portugal.

2 Institute of Wood Biology and Wood Technology, Büsgenweg 4 - 37077, Germany

^Corresponding author: dbL@isep.ipp.pt

Received: 12.06.2013 Accepted: 12.05. 2014
} 


\section{INTRODUCTION}

The influence of chemical modification on the strength properties has not been widely reported for softwood in general and for Maritime pine in particular. Scots pine is the most studied pine wood in EU and references properties according to EN 384 are well known. Modulus of elasticity (MOE) did not change significantly at indoor condition, modulus of rupture (MOR) tends to reduce with different extent mainly for modified wood with condensate resins. On the other hand, the less known properties according to EN 384, as the compression, tensile and shear strength are not explored.

As a consequence of the chemical modification, especially with cell wall reaction, wood material becomes brittle and, in some cases, large impact bending strength (IBS) reduction was presented (Epmeier et al. 2004, Lande et al. 2004, Bollmus et al. 2010, Krause 2006). The main reason to explain it is: i) the acidic hydrolysis of the polysaccharides as a result of the use of magnesium chloride as catalyst and ii) by the movement limitation of the cell wall due to the cross-linking with resin (Evans and Schmalzl 1989, Mai et al. 2007, Xie et al. 2007, Dieste et al. 2008). Similar causes were report to affect the mechanical properties of solid wood modified with resins in a phenomenon described as embrittlement (Rowell 1996, Lande et al. 2004).

Recently, Portuguese pinewood has been modified following the global trend, as Southern Yellow pine in United States and Scots pine in European Union (Rowell 2005, Hill 2006). Esteves et al. (2008) have shown the enhanced durability performances, dimension stability and no significant changes in the reference mechanical properties, i.e. MOE and MOR, modulus of elasticity and modulus of rupture, of Maritime pine by heat modification had no significant changed. Esteves et al. (2009) have shown similar results with furfuryl alcohol resin as presented before with heat modification.

Cell wall reaction with condensate resins (1,3-dimethylol-4,5-dihydroxyethyleneurea DMDHEU and $\mathrm{N}$-methylol melamine formaldehyde MMF) and deposited material filling the lumen of wood cells (with tetra-alkoxysilane-TEOS and wax) are representative of eco-efficient methods of chemical modification used in US and EU. The concentration levels were chosen for comparison reasons, between chemicals used and natural wood. In addition, for resin based modification, low concentrations are related without brittleness and low durability performance against fungi organisms. While higher concentrations have high durability and some mechanical properties are undermined - embrittlement.

The aim of this work was to investigate the effect of two types of chemical modification on the mechanical properties of Portuguese softwood Maritime pine. Especial focus as given in the less known properties and references properties according to EN 384 .

\section{EXPERIMENTAL}

\section{Materials and methods}

Flawless specimens of pure sapwood of Maritime pine species (Pinus pinaster Ait.) with 2-3 mm annual ring width and a mean dry density of $525 \mathrm{~kg} \cdot \mathrm{m}^{-3}$ were chemically modified with four methods with two types of active principle:

- The cell wall modification with condensated resin: 1,3-dimethylol-4,5-dihydroxyethyleneurea (DMDHEU) and N-methylol melamine formaldehyde (MMF) and, - The lumen fill modifications with tetraethoxysilane (TEOS) and wax (amid and montan wax). 
The modifications were carried out at facilities of the Wood Biology and Wood Technology of the Georg-August-Universität (Göttingen, Germany) at semi-industrial pilot plant. Specimens were impregnated with different solutions (DMDHEU, MMF, TEOS and wax) in a full cell process with a vacuum step of 30 min and 2 hours pressure step with $1200 \mathrm{kPa}$. For resins curing, all specimens were dried for $48 \mathrm{~h}$ at room temperature. Then, for resin, the wood material was stored four days in an oven with 5 steps of temperature increase every day $\left(10^{\circ} \mathrm{C}\right)$ until the temperature of $90^{\circ} \mathrm{C}$ was reached. The curing process was abbreviated as oven process (o) because the material was held in oven conditions. The steam dryer curing process (s) was also used for modification with MMF resin. Specimens were stacked in the steam dryer where, between each specimens, spacers with $20 \mathrm{~mm}$ thick were inserted to ensure good air circulation. The main part of the reaction process consisted of a temperature phase at $90^{\circ} \mathrm{C}$ for $36 \mathrm{~h}$, which was enclosed by a heating and wet phase as high as possible, $90 \% \mathrm{RH}$ app (Krause 2006). The following assignment was used, i1o and i2o or i1s and i2s, respectively. More information about these chemical modifications can be consulted in Lopes et al. (2014). Table 1 shows a summarized overview of the assignments for all modifications used in this study. As a summary, three levels of concentration with DMDHEU ( $0,8 \mathrm{M}$ and $1,3 \mathrm{M}$ as well as $2,3 \mathrm{M})$, using $4 \%$ magnesium nitrate relative to the mass of the solution as catalyst, were used. Two levels of modification with TEOS and two types of wax were used.

Table 1. Abbreviation of modifications: Resin based, DMDHEU with three concentrations $(0,8 \mathrm{M}$ $1,3 \mathrm{M}$ and 2,3M) and MMF with two concentrations and two types of curing; as lumen fill modification, TEOS and wax with two level of modification were used too.

\begin{tabular}{|c|c|c|c|c|c|c|c|}
\hline & Concentrations & Low & Medium & \multicolumn{4}{|c|}{ High } \\
\hline & Curing process & oven & steam & oven & steam & oven & $\therefore$ \\
\hline $\begin{array}{l}\text { Cell wall } \\
\text { reaction }\end{array}$ & $\begin{array}{l}\text { DMDHEU } \\
\text { MMF }\end{array}$ & $\begin{array}{ll}\text { D1 } & \text { D2 } \\
& \text { i1o }\end{array}$ & i1s & $\begin{array}{l}\text { D3 } \\
\text { i2o }\end{array}$ & $\mathrm{i} 2 \mathrm{~s}$ & & \\
\hline Lumen fill & $\begin{array}{l}\text { TEOS } \\
\text { Amid wax } \\
\text { Montan wax }\end{array}$ & & & 1 & & $\mathrm{~T} 2$ & $\begin{array}{l}\text { WA } \\
\text { WL }\end{array}$ \\
\hline
\end{tabular}

Before all impregnations, wood material was dried over $24 \mathrm{~h}$ at $103^{\circ} \mathrm{C}\left(\mathrm{W}_{\text {unmodified }}\right)$. After impregnations and curing, wood material was dried to access the dry weight $\left(\mathrm{W}_{\text {modified }}\right)$. The weight percent gain was obtained by the difference between both weight measurements for each type of modification methods. The concentration of solution correlate with weight percent gain (WPG) acquired by the wood material. In all figures presented next ones Star with five nozzle shows the WPG for modified wood.

Mechanical tests were conducted in a $10 \mathrm{kN}$ Zwick/Roell ZMART.pro universal testing machine (Ulm, Germany) with $1 \%$ load accuracy and the strain at the middle length of the specimens (with uniform crosssection) was obtained using an MFA 25 extensometer, gauge length $50 \mathrm{~mm}$ with $0,5 \%$ accuracy. MOE, MOR, WML- work maximum load in three point bending $(3 \mathrm{pb})$ and shear strength were determined.

Compression tests, parallel and perpendicular to the grain, tensile strength and associated stiffness's were conducted in a $100 \mathrm{kN}$ Zwick/Roell ZMART.pro universal testing machine (Ulm, Germany) with 1\% load accuracy. In these properties, since no strain gauges were attached to the samples, due to the small size of them, the crosshead-displacements were recorded and used for the strain calculation. Thus, the absolute strain is not entirely correct, but still useful for comparatives purposes between modified and unmodified specimens. 
The IBS was determined using the Charpy pendulum according to DIN 52189 standard. For the energy calculation $\left(\mathrm{A}_{\mathrm{w}}\right.$ in $\left.\mathrm{kJ} \cdot \mathrm{m}^{-2}\right)$ the following equation was used, where $\mathrm{Q}$ is the energy required to fracture the test piece $(\mathrm{J})$, and $\mathrm{b}$ and $\mathrm{h}$ are the dimensions of the test piece in the radial and tangential directions $(\mathrm{mm})$.

$$
A_{w}\left[\mathrm{~kJ} \cdot \mathrm{m}^{-2}\right]=\frac{1000 \cdot Q}{b \cdot h}
$$

The $\mathrm{MOE}_{\mathrm{st}}$ was assessed in three points bending in dry and wet conditions at $30 \%$ and $87 \%$ of $\mathrm{RH}$ respectively. The difference in the static modulus of elasticity $\mathrm{MOE}_{\text {st }}$ between both climates for all un- and modified wood were used to calculate the SSE - stiffness stabilization efficiency:

$$
\triangle \mathrm{MOE}=\mathrm{MOE}_{\mathrm{dry}}-\mathrm{MOE}_{\text {humid }}
$$

To quantify the SSE of a modification process, the SSE ratio, expressed as a percentage, was calculated according to the following equation:

$$
\operatorname{SSE}[\%]=\frac{\Delta M O E_{\text {unmodified }}-\Delta M O E_{\text {modified }}}{\Delta M O E_{\text {unmodifed }}} \cdot 100
$$

The $\triangle \mathrm{MOE}_{\text {modified }}$ is the average of MOE variation for each group (10 replicates) of modified specimens and the $\triangle \mathrm{MOE}_{\text {unmodified }}$ is the average of MOE variation of the unmodified controls.

Table 2 shows a summarized overview about size and number of specimens and followed standards in

\begin{tabular}{|c|c|c|c|c|}
\hline Strength Property & & $\begin{array}{c}\text { Dimension } \\
{\left[\mathrm{mm}^{3}\right]}\end{array}$ & $\begin{array}{c}\mathrm{n} \\
{[\mathrm{ud}]}\end{array}$ & Standard \\
\hline \multicolumn{5}{|l|}{ Compression strength } \\
\hline Parallel to the grain & $f_{c, o}$ & $30^{\mathrm{x}} 20^{\mathrm{x}} 20$ & 10 & DIN 52185 \\
\hline Perpendicular to the grain & $f_{c, 90}$ & $60^{\mathrm{x}} 20^{\mathrm{x}} 20$ & 10 & DIN 52185 \\
\hline \multicolumn{5}{|l|}{ Bending } \\
\hline Modulus of rupture & MOR & $200^{x} 10^{x} 10$ & 10 & DIN 52186 \\
\hline Work maximum load & WML & $200^{x} 10^{x} 10$ & 10 & DIN 52186 \\
\hline Shear & $\mathrm{f}_{\mathrm{v}, \mathrm{o}}$ & $20^{\mathrm{x}} 20^{\mathrm{x}} 20$ & 20 & DIN 52187 \\
\hline Parallel tension & $f_{t, o}$ & $300^{x} 20^{x} 15$ & 20 & DIN 52188 \\
\hline Impact bending & IBS & $150^{\mathrm{x}} 10^{\mathrm{x}} 10$ & 20 & DIN 52189 \\
\hline \multicolumn{5}{|l|}{ Stiffness } \\
\hline Modulus of elasticity, bending & $\mathrm{MOE}_{\mathrm{st}}$ & $200^{\mathrm{x}} 10^{\mathrm{x}} 10$ & 10 & DIN 52186 \\
\hline Parallel tension & $\mathrm{E}_{\mathrm{t}, \mathrm{o}}$ & $300^{x} 20^{x} 15$ & 20 & DIN 52188 \\
\hline Perpendicular compression & $E_{c, 90}$ & $60^{\mathrm{x}} 20^{\mathrm{x}} 20$ & 10 & DIN 52185 \\
\hline
\end{tabular}
the experimental work for each chemical modification methods and unmodified control.

Table 2. Properties, specimen size LRT, applied standard and the number of specimens (n).

In the next figures all material properties were characterized by mean $(\mathrm{x})$, the median (horizontal line in the box plot) and standard deviation (rectangular box) for unmodified and modified wood. For comparative purposes, t-tests analyses were carried out to verify whether a change was significant or not. The level for significance was set at $\mathrm{p}<0,05$. The whisker plots display the 5 and $95 \%$ percentile range. 


\section{RESULTS AND DISCUSSION}

\section{Stiffness}

Figure 1 shows the stiffness $\left(\mathrm{MOE}_{\mathrm{st}}\right)$ at indoor conditions $(65 \% \mathrm{RH})$ and the SSE observed. The WPG is one indicative of the concentration level of the solution used or the degree of modification introduced. Despite different WPG found, none modification process used in this study changed significantly the MOE, Figure 1a.

Short-term loads and lower level of stress are the main reason.

Scots pine and Beech modified with resins DMDHEU and MMF did not change the MOE (Bollmus 2011, Krause 2006). Specimens with lumen fill: Scholz et al. (2009) with Scots pine modified with the same type of wax used in this study has shown similar results with no significant changes in the MOE. Donath (2004) and Donath et al. (2004) have shown no effect in the Scots pine modified with TEOS.

Epmeier et al. (2004) did a large study with well-documented provenance material and no significant effect was showed. At indoor conditions, they showed that the high variability in unmodified wood was kept in the modified wood.

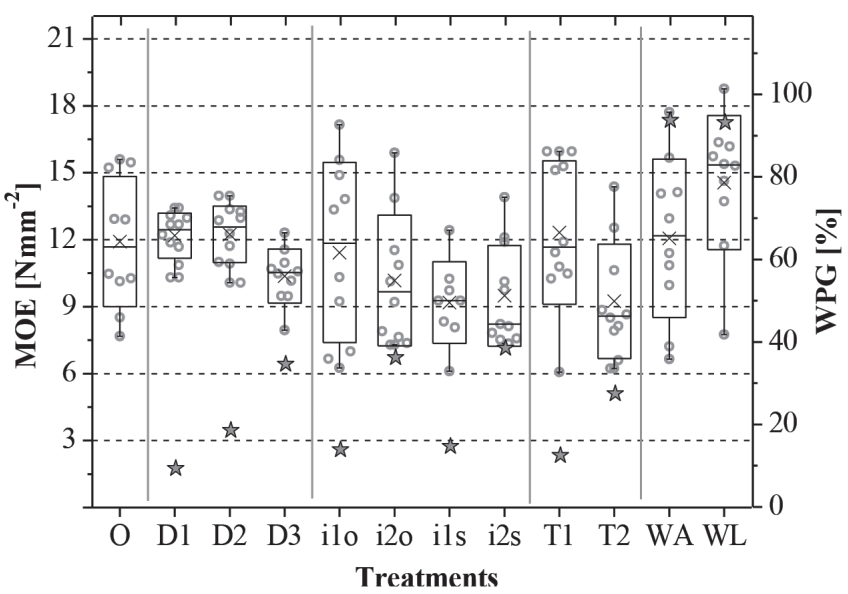

(a)

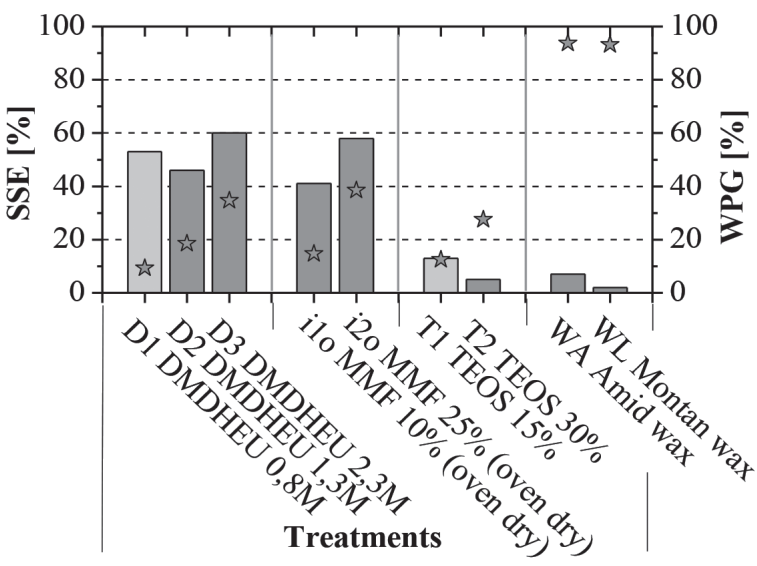

(b)

Figure 1. (a) MOE according to DIN 52 186, (b) SSE (between 87 and $30 \%$ of environmental RH) and WPG (it).

For features of wood material Table 2. 
The higher the SSE - stiffness stabilization efficiency is, the higher is the stabilization effect of the chemical modification. An SSE of $60 \%$, e.g., means that the MOE of the modified wood differs $60 \%$ less between two climates than the MOE of the unmodified wood. A negative SSE indicates that the modification made the material more sensitive to moisture changes and the MOE variation $(\triangle \mathrm{MOE})$ in the modified wood specimens was higher than the unmodified ones. The SSE varied substantially, mainly for resin-based modification. In the lumen fill modification (TEOS and wax), between both RH environments, no effect was found, Figure $1 \mathrm{~b}$.

Mainly in the resin based modification, an enhanced behaviour for SSE will be expected due to the behaviour at wet conditions. As suggested by Krause (2006), furfurylated wood (wood modified by furfuryl alcohol) has similar behaviour to DMDHEU resin modification. Lande et al. (2004) found high at moderate SSE, app. 30 and $60 \%$ with 15 and $47 \%$ of WPG, respectively. The good relation with moisture showed in the physical properties (low equilibrium moisture content, EMC and high dimensional stability, ASE) is the main reason (Lopes et al. 2013). In this study, different concentrations of DMDHEU resin have shown similar SSE, 45 up to $60 \%$. Regarding to unmodified wood, similar reduction was shown in the EMC variation between wet and dry conditions rather than the anti-swelling efficiency - ASE (Lopes et al. 2013).

In our study, modification with MMF resin has shown different SSE, 40 up to 70\%, respectively for low and high concentration. The SSE follows the outcome regard to the ASE rather than the EMC variation between wet and dry conditions (Lopes et al. 2013). The same study showed that the EMC variation was in the less extend than SSE.

Epmeier et al. (2004) with MMF resin (15\%) presented results in the other way around, with similar EMC variation has shown SSE near null. Epmeier et al. (2007a) and Epmeier et al. (2007b) have shown a surprise increase of $\mathrm{MC}$ in MMF resin related to control. At one hand, changes in EMC did not necessarily produce a change in MOE (Norimoto et al. 1992). On the other hand, the way of calculation the EMC (dry weight after treatments, against to dry weight before in ours treatments) and the size of samples, seems to explain the differences. Small-scale specimens tend to present more accurate results due to the uneven distribution of chemical at the specimens cross-section.

Modification with filling the lumen (with TEOS and wax) has shown no effect in the ASE or EMC variation between different environments conditions related to unmodified wood. The same effect happened in the SSE.

The deposit material in the lumen, and which filling it with TEOS and wax, didn't react with cell wall, then any effect on this short-term mechanical properties will be expected.

\section{Bending strength}

Figure 2 shows the bending strength (MOR) according to DIN 52 186. The resin based modification with DMDHEU (D1 - 0,8M) has shown a slight but not significant reduction in the strength, MOR and WML. The latter properties, MOR and WML, between un- and modified wood performed in a similar way. In medium and high concentration levels of resin (D2 and D3 with 1,3 and 2,3M) a significant reduction up to $27 \%$ were found, despite the difference in the WPG.

Specimens modified with MMF resin did not show a significant reduction, up to $20 \%$. Between both curing processes (oven and steam drier) no effect was found.

The bending strength in the lumen fill modification, TEOS did not show any effect and both types of wax increased up to $35 \%$.

Similar results to this study were shown by Bollmus (2011) and Scholz et al. (2009). The former with modified Beech with DMDHEU resin showed a decreasing MOR up to 20\%. The latter with Scots pine with the same type of wax, they showed an increase MOR up to $28 \%$. 


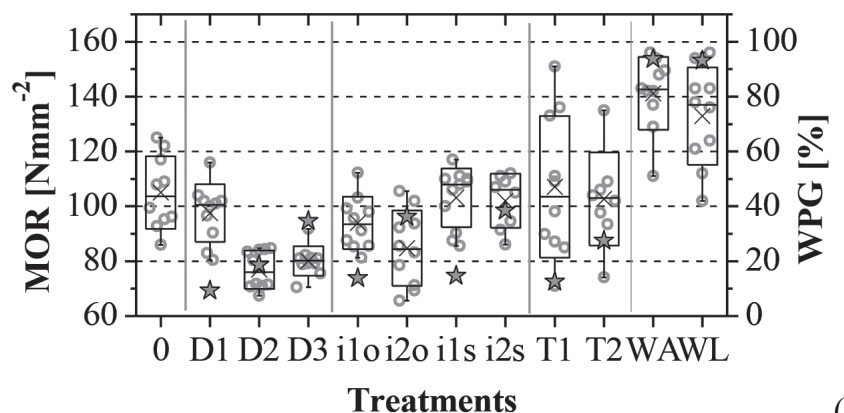

(a)

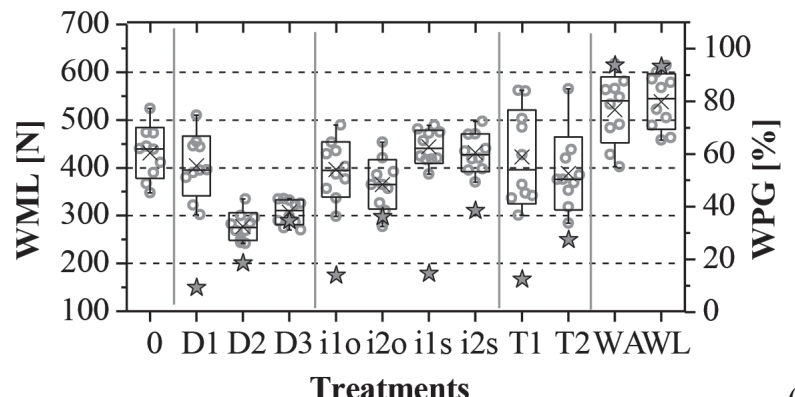

(b)

Figure 2. (a) MOR, (b) WML and WPG (ל)

For abbreviations table 1 and for features of wood material see Table 2.

According to ASTM D143-83 different rupture patterns for un- and modified wood could be identified. Rupture patterns for bending were similar to rupture patterns for the IBS test showed in Figure 6. In the cell wall modification with different levels of DMDHEU resin, only one type of rupture was shown: Brash tension with the influence of brittleness material. In the MMF resin modification with oven drier curing process and low level of modification, cross-grain and simple tension ruptures were presented. High concentration of MMF resin, and both types of curing process, typical brash tension was found. The brash tension or brittleness material was due to the acidification and the movement limitation caused by resin.

In the lumen fill modification (TEOS and wax) no difference in the rupture modes was presented to unmodified wood specimens.

\section{Compression strength}

Figure 3 shows the compression strength parallel to the grain. Different concentrations of DMDHEU resin have shown a significant increase of compression strength, up to 55\%. Specimens modified with MMF resin increased the compression strength up to $30 \%$, and did not show significant difference between both curing processes. Cell wall modification (DMDHEU and MMF) showed a significant increasing of compression strength.

In the lumen fill modification: TEOS did not show a significant effect on the compression strength but both types of wax (amid or montan) have shown a significant increasing, up to $30 \%$.

The main explanation seems to be the resin and wax incorporation in the lumen, of the wood material. The same principle leads to the increasing of hardness according to Rowell (1983) and Hill (2006). 


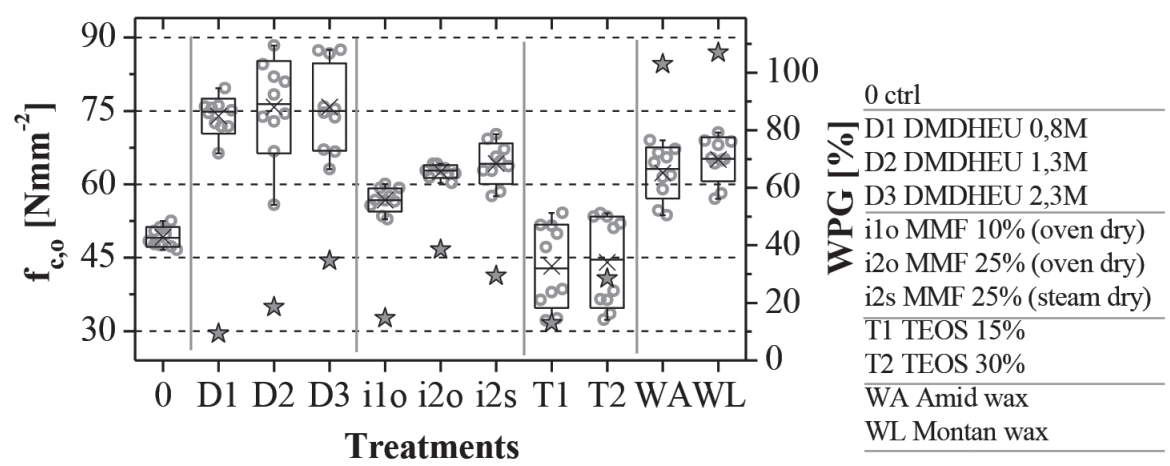

Figure 3. Compression strength parallel to the grain and WPG ( $\mathbf{z}$ ).

For features of wood material see Table 2 .

Figure 4 shows the transversal compression strength and stiffness, perpendicular to the grain and in the tangential direction. The compression strength in the cell wall modification with different concentrations (DMDHEU and MMF resin) showed a significant increase up to $125 \%$, Figure 4a. Both curing process in the MMF resin did not show significant difference. In the lumen fill modification: TEOS did not show a significant effect on the transversal compression, but both types of wax showed a significant increase of transversal compression, up to $230 \%$ (Figure 4a).

Gindl et al. (2003) with Scots pine modified with MMF resin have shown similar compression strength perpendicular to the grain in the tangential direction. Beech modified with DMDHEU resin showed an improvement up to $40 \%$ (Bollmus 2011). Between both later authors, it seems that resin showed less effect on the hardwood compression strength than softwood did.

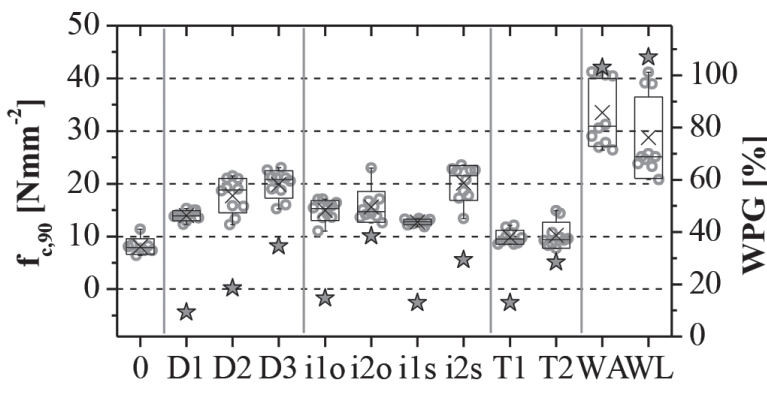

Treatments

(a)

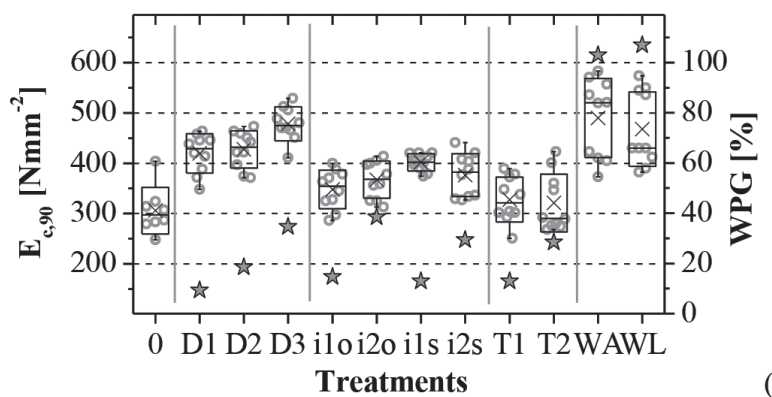

(b)

Figure 4. (a) Perpendicular compression strength, (b) MOE and WPG (לt). For abbreviations table 1 and for features of wood material see Table 2. 
Figure $4 \mathrm{~b}$ shows the stiffness perpendicular to the grain in the tangential direction (Ec,90). Cell wall modifications with different concentrations of DMDHEU resin have shown a significant increase up to $60 \%$. MMF resin has shown an increase up to $30 \%$. In the latter modification, both curing process did not show significant difference.

In the lumen fill modification, TEOS has shown no significant effect and both types of wax (amid and montan) have shown a significant increase, up to $75 \%$.

Shear strength

Figure 5 shows the shear strength parallel to the grain according to DIN 52187 standard. Cell wall modification (with DMDHEU and MMF resins) showed a significant reduction up to $30 \%$, and it was similar to the bending behaviour. The embrittlement effect imparted by resin was also seen on the shear strength. In this study with resins based modification, softwood pine acted similarly to hardwood Beech modified (Bollmus 2011). A shear reduction was also reported by Dreher et al. (1964) in Rowell (2005) with acetylated Southern Yellow pinewood.

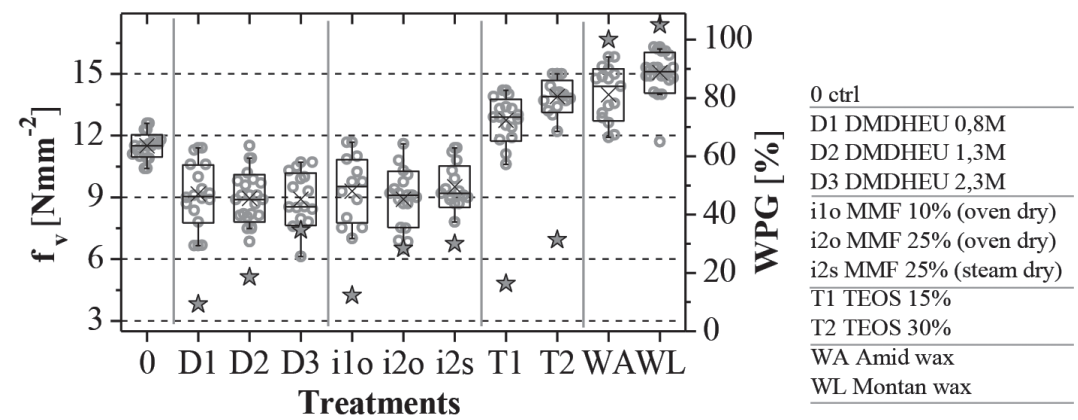

Figure 5. Shear strength parallel to the grain and WPG (z).

For features of wood material see Table 2.

In the lumen fill modification, shear strength were increased. A significant effect was found for wax modified specimens and for high concentration of TEOS, up to $30 \%$.

\section{Impact bending strength}

Figure 6 shows the IBS determined using the Charpy pendulum. This variable is usually used to translate the embrittlement of the modification in to the wood material. In the cell wall modification: DMDHEU resin has shown a significant reduction up to $65 \%$; MMF resin has shown a reduction up to $30 \%$, only significant for high level of concentration. In the high concentration level of MMF and between both curing processes, non-significant effect on the IBS was found.

In the lumen fill modification: TEOS did not show significant effect and both types of wax have shown a slightly, not significant, increasing of IBS, up to $22 \%$. 




Figure 6. IBS and WPG (tz).

For features of wood material see Table 2.

According to ASTM D143-83 different rupture patterns could be identified. Figure 7 shows the IBS rupture patterns for un- and modified wood with the most different behaviours. In the unmodified pinewood, a fibrous rupture in the compression fibres was found. The cell wall modification with DMDHEU resin has shown two types of ruptures mode with the brittleness material influence: a right broken and a blunt rupture for low and other levels of modification, respectively. In both concentration levels of MMF resin and both curing processes, the rupture mode did not show significant difference and occurred in the tensile fibres.

In the lumen fill modification TEOS did not show any difference to unmodified wood, despite of both levels of modification (17 and $28 \%$ of WPG). In modified wood with both types of wax, the rupture mode occurred in the tensile fibres.

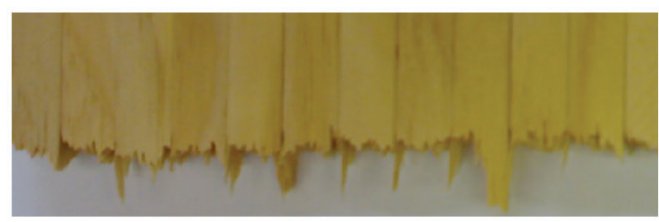

(a)

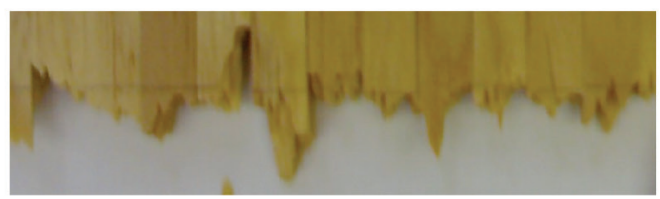

(c)

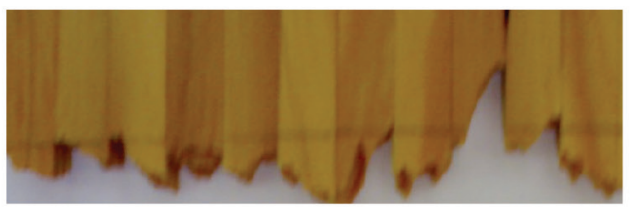

(b)

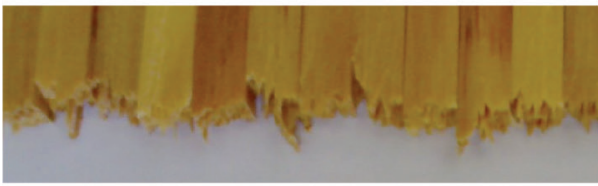

d)

Figure 7. Rupture patterns for: (a) Unmodified; (b) DMDHEU resin, D3 (2.3M); (c) MMF resin (32\% WPG) and (d) Wax (108\% WPG), for specimens 10x10x150 RTL mm. 
The IBS was reported as the most adversely affected property by cell wall modifications wood, with a reduction up to 60\% (Rapp and Sailer 2001, Johansson and Morén 2006, Goldstein 1955 in Lande et al. 2004, Xiao et al. 2010, Epmeier et al. 2004, Lande et al. 2004, Bollmus 2011). However, in acetylated Radiata pinewood, Tjeerdsma and Pfeiffer (2006) did not show significant difference to the unmodified wood.

An opposite trend, with an improvement of mean IBS, was showed for Scots pine modified with wax (Scholz et al. 2009).

The embrittlement rupture mode in the DMDHEU resin was not surprisingly, because the effect of the acidic hydrolysis together with the effect of the resin deposit on the cell wall (entrapment). The latter effect in the higher concentration of MMF resin did not occur because other factor aroused. Probably the hardness or compression strength increasing was masked the effect of the resin deposit. Compression and tension strength were evolved in different ways for wax and MMF modification. Probably the tensile fibres rupture mode was occurred owing to the significant increase of hardness or compression strength material (MMF and wax modifications). The role of the latter imparted properties on the equilibrium of the cross section was crucial, the neutral axis moves to the large imparted properties. Compression increased significantly and tensile strength did not change significantly in MMF and wax modification, at one hand. On the other hand, the maximum tensile strength was reached more quickly. The IBS strength was followed by the tensile strength behaviour.

\section{Tensile strength}

Figure 8a shows the tensile strength parallel to the grain. Wood specimens modified with cell wall reaction have shown a significant reduction up to $45 \%$ with DMDHEU resin. It is noted the associated small standard deviation (see rectangular box plot dimension). Modified wood with MMF resin did not show significant difference between both curing processes and have shown a slight, not significant, reduction effect in the tensile strength, up to $10 \%$.

In the lumen fill modification (with TEOS and wax) the increase of tensile strength was not significant, up to $22 \%$. 


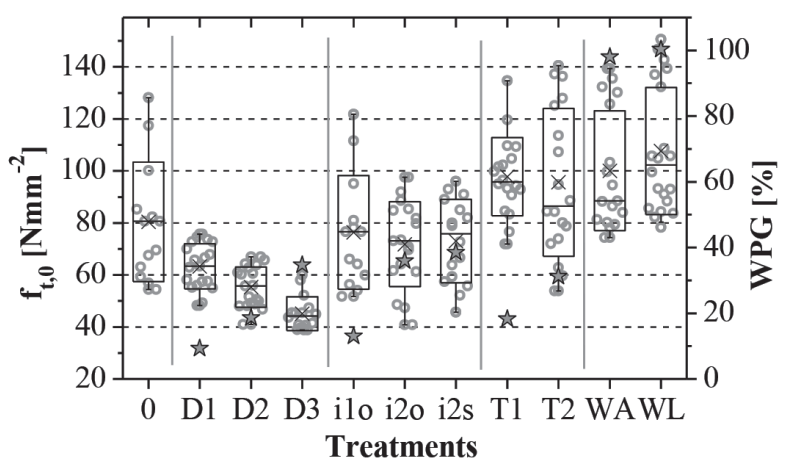

(a)

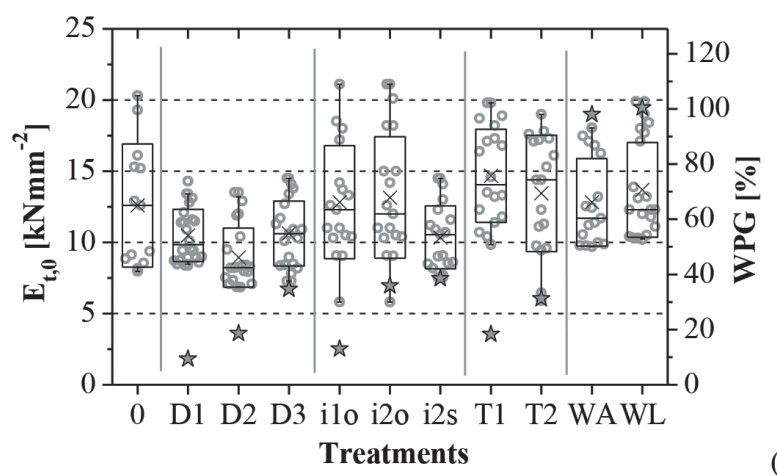

(b)

Figure 8. (a) Tensile strength, (b) stiffness in the longitudinal direction and WPG (לt). For abbreviations and features of wood material see Table 2.

Figure $8 \mathrm{~b}$ shows the tensile stiffness parallel to the grain. For both types of modification, cell wall reaction with resin based (DMDHEU and MMF) and lumen-fill modification (TEOS and wax), no significant effect on the tensile stiffness were found. DMDHEU resin has shown less scatter result associated with slight reduction.

In the cell wall modification, the resin reacts with cell wall of wood fibres, into the wood. The wood became harder, known as embrittlement effect. In bending, the arresting fibres didn't let material deform / slip. On this short-term mechanical property, the arresting fibres were the main responsible for the embrittlement effect.

Positive or negative improvements on bending strength were found in cell wall reaction or lumen fill modification. The bending behaviour has involved compression and tensile strength at the same time. In the modified wood, the compression strength increased and the tensile strength changed in different way, figure 8 (decreasing for cell wall reaction and increasing for lumen fill modification). It is true and well established that the reduction on the cell wall modification was conditioned by the embrittlement effect imparted by the resin, DMDHEU and MMF (Rowell 1983, Mai et al. 2007, Xie et al. 2007, Dieste et al. 2008). However and from this study, it seems that MOR was conditioned by the behaviour of tensile strength, at one hand.

Santos (2009) and Machado and Palma (2010) with unmodified Maritime pine have shown similar mean strength and stiffness in tension parallel to the grain with standard size compared to small-size specimens in this study. 
In the cell wall modified specimens, with MMF and especially with DMDHEU resin, tensile strength is expected to be reduced, as a consequence of the acidic hydrolysis of the hemicelluloses (Xie et al. 2007). However, Scots pine veneers modified with MMF resin did not cause any tensile strength reduction compared to unmodified veneers (Mai et al. 2007). Specimens modified with MMF resin showed less embrittlement effect in the IBS reduction, however a reduction up to $30 \%$ were found. Therefore, no significant effect on tension strength was found. The embrittlement effect was not revealed in modified wood with MMF resin.

Bollmus (2011) with Beech modified with DMDHEU resin with similar concentration levels showed a reduction in tensile strength, up to $60 \%$. Maritime pine wood has shown a reduction in the tensile strength up to $45 \%$. Unlike what happens with the effect of modification imparted in compression strength between soft- and hard-wood, it seems that the DMDHEU resin showed large reduction in the tensile strength on hard- than in the soft-wood did. Tensile stress changes followed closely the enhancement on the absorption energy (IBS) for DMDHEU modification. For this purpose, the main reasons were the embrittlement effect associated and helped with lower EMC.

In different environments, changes in EMC presented by different modifications as well as the EMC variation did not fit with the tensile strength changes.

\section{CONCLUSIONS}

Wood modification can improve some mechanical properties and turn the wood into an engineered building product. Modulus of elasticity (MOE) at indoors conditions appeared to be relatively unaffected by modifications, even though high SSE in varies extend were obtained. At one hand, in the resin based modification the enhancement behaviour on wet conditions improved up to $60 \%$. On the other hand, for modification with materials deposited in the lumen fill (with TEOS and wax), between dry and wet conditions, have shown no effects on SSE.

In modified wood, the modulus of rupture (MOR) was changed in different ways, with significant reduction in the DMDHEU resin, up to $30 \%$. On the other hand, a positive and significant improvement in the wax modification was found, up to $30 \%$. Frequently, ruptures occurred abruptly and a brittle behaviour appeared for cell wall modification (DMDHEU and MMF resin). The lumen fill modification (with TEOS and wax) kept the unmodified wood features in the rupture mode.

Except for modified wood with TEOS, all modifications used in this study have shown an improvement of compression strength in $\mathrm{L}$ and $\mathrm{T}$ directions, up to $55 \%$.

In addition, shear and tensile strength as well as the ability to absorb the impact energy (IBS) appears to be affected more negatively as better the compression strength becomes. 


\section{REFERENCES}

ASTM D143-83. 2009. Standart methods of testing, small clear specimens of timber. American Society for Testing and Materials.

Bollmus, S.; Rademacher, P.; Militz, H. 2010. Material evaluation and product performances of beech wood modification with 1,3-dimethylol-4,5-dihydroxyethylenurea (DMDHEU). In: Hill CAS, Militz H.; Andersons B (Hg.) The Fifth European Conference on Wood Modification ECWM5 Proceedings. 5th European Conference on Wood Modification, Riga, 15-22.

Bollmus, S. 2011. Biologische und technologische Eigenschaften von Buchenholz nach einer Modifizierung mit 1,3-dimethylol-4,5-dihydroxyethyleneurea (DMDHEU). PhD dissertation Georg-August-Universitat Goettingen, ISBN 978-3-86955-708-3 (in German).

Dieste, A.; Krause, A.; Bollmus, S.; Militz H. 2008. Physical and mechanical properties of plywood produced with 1.3-dimethylol-4.5-diyhdroxyethyleneurea (DMDHEU) - modified veneers of Betula sp. and Fagus sylvatica. Holz als Roh-und Werkstoff 66: 281-287.

DIN 52 185. 1976. Testing of wood: Compression test parallel to the grain. Deutsches Institut Für Normung e.V. Normen über Holz, Biegeversuch, Beuth, Berlin, September (in German).

DIN 52 186. 1978. Testing of wood; bending test. Deutsches Institut Für Normung e.V. Normen über Holz, Biegeversuch, Beuth, Berlin (in German).

DIN 52 187. 1979. Testing of wood; determination of ultimate shearing stress parallel to grain. Deutsches Institut Für Normung e.V. Normen über Holz, Biegeversuch, Beuth, Berlin, July (in German).

DIN 52 188. 1979. Testing of wood: Determination of ultimate tensile stress parallel to grain. Deutsches Institut Für Normung e.V. Normen über Holz, Berlin, May (in German).

DIN 52 189. 1981. Schlagbiegeversuch. Teil 1: Bestimmung der bruchschlagarbeit. Deutsches Institut Für Normung e.V. Normen über Holz, Biegeversuch, Beuth, Berlin, September (in German).

Donath, S. 2004. Treatment of wood with silanes. PhD dissertation, Georg-August-Universitat Goettingen, Germany, ISBN 978-3-87915-718-2.118p,

Donath, S.; Militz, H.; Mai, C. 2004. Wood modification with alkoxysilanes. Wood Science and Technology 38: 555-566.

Dreher, W.A.; Goldstein, I.S.; Cramer, G.R. 1964. Mechanical properties of acetylated wood. Forest Products Journal 14(2): 66-68.

EN 384. 2004. Structural timber - Determination of characteristic values of mechanical properties and density. CEN Comité Européen de Normalisation. Bruxelles.

Epmeier, H.; Westin, M.; Rapp A. 2004. Differently modified wood: Comparison of some selected properties. Scandinavian Journal of Forest Research 19(5): 31-37.

Epmeier, H.; Johansson, M.; Kliger, R.; Westin, M. 2007a. Material properties and their interrelation in chemically modified clear wood of Scots pine. Holzforschung 61: 34-42. 
Epmeier, H.; Johansson, M.; Kliger, R.; Westin, M. 2007b. Bending creep performance of modified timber. Holz als Roh- und Werkstoff 65: 343-351.

Esteves, B.M.; Domingos, I.J.; Pereira, H.M. 2008. Pine wood modification by heat treatment in air. BioResource 3(1): 142-154.

Esteves, B.; Nunes, L.; Pereira, H. 2009. Furfurylation of Pinus pinaster Wood. In: Englund F, Hill CAS, Militz H, Segerholm BK (Hg.) The Fourth European Conference on Wood Modification. $4^{\text {th }}$ European Conference on Wood Modification, Stockholm, 415-418.

Evans, P.D.; Schmalzl, K.J. 1989. A quantitative weathering study of wood surfaces modified by chromium VI and iron III compounds. Part 1. Loss in zero-span tensile strength and weight of thin wood veneers. Holzforschung 43: 289-292.

Gindl, W.; Muller, U.; Teischinger, A. 2003. Transverse compression strength and fracture of spruce wood modified by melamine-formaldehyde impregnation of cell walls. Wood and Fiber Science 35(2): 239-246.

Goldstein, I.S. 1955. The impregnation of wood to impart resistance to alkali and acid resistance. Forest Products Journal 5: 265-267.

Hill, C.A.S. 2006. Wood modification chemical, thermal and other processes. John Willey \&Sons, Ltd, ISBN 13:978-0-470-02172-9 England.

Johansson, D.; Morén, T. 2006. The potential of colour measurement for strength prediction of thermally treated wood. Holz als Roh-und Werkstoff 64: 104-110.

Krause, A. 2006. Holzmodifizierung mit N-Methylolvernetzern. PhD Dissertation, Georg-AugustUniversitat Goettingen, 219 pg (in German).

Lande, S.; Westin, M.; Schneider, M. 2004. Properties of furfurylated wood. Scandinavian Journal Forest Research 19(5): 22-30.

Lopes, D.B.; Mai, C.; Militz, H. 2013. Physical properties of chemical modified Portuguese pinewood. Ciência \& Tecnologia dos Materiais 25:120-127.

Lopes, D.B.; Mai, C.; Militz, H. 2014. Marine Borers Resistance of Chemically Modified Portuguese wood. Maderas.Ciencia y Tecnología 16(1):109-124.

Machado, J.S.; Palma, P. 2010. Predicting the mechanical behaviour of solid pine timber elements through non and semi destructive methods. $11^{\text {th }}$ World Conference on Timber Engineering, Trento - Italy, 24-24 June.

Mai, C.; Xie, Y.; Xiao Z.; Bollmus, S.; Vetter, G.; Krause, A.; Militz, H. 2007. Influence of the modification with different aldehyde-based agents on the tensile strength. $3^{\text {th }}$ European Conference on Wood Modification, pg 49-56 Cardiff UK.

Norimoto, M.; Gril, J.; Rowell, R.M. 1992. Rheological properties of chemically modified wood: relationship between dimensional and creep stability. Wood and Fiber Science 24(1): 25-35.

Rapp, A.O.; Sailer, M. 2001. Oil heat treatment of wood in germany - state of the art, review on heat treatments of wood. Edited by Andreas O. Rapp , Hamburg BFH, ISBN 3-926301-02-3, 45-62p. 
Rowell, R.M. 1983. Chemical modification of wood. Commonwealth Forestry Bureau Forest Products Abstracts 6: 363-382.

Rowell, R.M. 1996. Physical and mechanical properties of chemically modified wood. In: Rowell RM (eds) Chemical modification of lignocellulosic materials. Marcel Dekker, New York, pp 295-310.

Rowell, R.M. 2005. Handbook of wood chemistry and wood composites: blends and composites, Chapter 14 Chemical Modification Wood. Edited by Stoyko Fakirov, Debes Bhattacharyya, ISBN 978-3-446-40591-2.

Santos, J.A. 2009. Estudo de modelos e caracterização do comportamento mecânico da madeira. $\mathrm{PhD}$ dissertation, Universidade do Minho, Portugal-Guimarães (in Portuguese).

Scholz, G.; Krause, A.; Militz, H. 2009. Capillary water uptake and mechanical properties of wax soaked Scots pine. IV European Conference on Wood Modification, pag 209-212, Stockholm, Sweden 27-29, April.

Tjeerdsma, B.F.; Pfeiffer, E. 2006. Impact bending strength. AccoyaTM wood, report code: 6.353, December.

Xiao, Z.; Xie, Y.; Militz, M.; Mai, C. 2010. Effects of modification with glutaraldehyde on the mechanical properties of wood. Holzforschung 64(4): 475-482.

Xie, Y.; Krause, A.; Militz, H.; Turkulin, H.; Richter, K.; Mai, C. 2007. Effect of treatments with 1,3-dimethylol-4,5-dihydroxyethyleneurea (DMDHEU) on the tensile properties of wood. Holzforschung 61: $43-50$. 